\title{
The effects of pH values on the formations of water soluble calcium
}

\section{1,3-propylenediaminetetraacetates}

Jun-Wei Dai, Xin Dong*, Zhao-Hui Zhou*

State Key Laboratory of Physical Chemistry of Solid Surfaces, College of Chemistry and Chemical Engineering, Xiamen University, Xiamen 361005, China

\begin{abstract}
A series of $\mathrm{pH}$ dependent water soluble calcium 1,3-propylenediaminetetraacetates $\left[\mathrm{Ca}\left(1,3-\mathrm{H}_{4} \text { pdta }\right)\left(\mathrm{NO}_{3}\right)_{2}\left(\mathrm{H}_{2} \mathrm{O}\right)_{2}\right]_{\mathrm{n}}$$$
\left[\mathrm{Ca}\left(1,3-\mathrm{H}_{2} \text { pdta }\right)\right]_{\mathrm{n}} \cdot \mathrm{nH}_{2} \mathrm{O}
$$
$\mathrm{K}_{4}\left[\mathrm{Ca}_{2}(1,3-\text { pdta })_{2}\right] \cdot 2 \mathrm{H}_{2} \mathrm{O} \cdot 2 \mathrm{CH}_{3} \mathrm{OH}(3)$ and $\mathrm{Ca}_{2}\left(\mathrm{H}_{2} \mathrm{O}\right)_{6}\left[\left(\mathrm{Ca}_{2}(1,3-\text { pdta })_{2}\left(\mathrm{H}_{2} \mathrm{O}\right)_{2}\right] \cdot 4 \mathrm{H}_{2} \mathrm{O}(4)\right.$ have been obtained from the direct reactions of calcium salts with 1,3-propylenediaminetetraacetic acid in different $\mathrm{pH}$ values and solvents respectively $\left(1,3-\mathrm{H}_{4} \mathrm{pdta}=\right.$ 1,3-propylenediaminetetraacetic acid). $\mathbf{1}$ is composed of one-dimensional chains bridged by 1,3- $\mathrm{H}_{4} \mathrm{pdta}$, where only two strong coordination sites are offered by $1,3-\mathrm{H}_{4}$ pdta ligands. While complex 2 features a three-dimensional (3D) structural motif and $\mathbf{3}$ forms a 2D structure. 4 also contains one-dimensional chain constructed by dimeric calcium 1,3-propylenediaminetetraacetates. Solution ${ }^{13} \mathrm{C}$ NMR spectra show that dimeric units in $\mathbf{3}$ dissociate into monomeric species in solution, which indicates that monomeric chelate is a dominant species in neutral and weak basic solution. It is notable that an obvious downfield shift $(\Delta \delta=2.09 \mathrm{ppm})$ is observed for methanol in $\mathbf{3}$ that differs from methanol in $\mathrm{D}_{2} \mathrm{O}$ solvent.
\end{abstract}

Keywords: Calcium; 1,3-Propylenediaminetetraacetic acid; MOF structures; Solution, NMR; Ethylenediaminetetraacetate 
* Corresponding authors. Tel.: +86 592 2184531; fax: +86 5922183047.

E-mail address: zhzhou@xmu.edu.cn (Z.-H. Zhou). 


\section{Introduction}

Calcium ion is an important alkaline-earth metal ion in biological systems. It is also the fifth-most-abundant dissolved ion in seawater by both molarity and mass, after sodium, chloride, magnesium and sulfur. The concentration of blood calcium is critical to the human health, where calcium usually binds with proteins [1-3]. Calcium plays an important role in the blood coagulation mechanism by activating thrombin to translate soluble fibrinogen into fibrous protein $[4,5]$. However, the blood in medicine is not suitable to be solidification by calcium ion. Ethylenediaminetetraacetic acid $\left(\mathrm{H}_{4}\right.$ edta) is an ideal anticoagulat to prevent blood clots due to its strong chelating ability [6,7]. Ethylenediaminetetraacetic acid can form especially stable complexes with many metal ions [8]. As a derivative of ethylenediaminetetraacetic acid, 1,3-propanediaminetetraacetic acid (1,3- $\left.\mathrm{H}_{4} \mathrm{pdta}\right)$ is also a tetrabasic acid with eight potential O-donor and two N-donor atoms. It has similar coordination ability with ethylenediaminetetraacetic acid. However, the 1,3- $\mathrm{H}_{4} \mathrm{pdta}$ can form a more flexible chelating ring due to the longer diamine chain when employed as a multidentate ligand. Up to now, a series of isolated chelates such as, $\left[\mathrm{M}^{\text {,II }}\left(\mathrm{H}_{2} \mathrm{O}\right)_{6}\right]\left[\mathrm{M}^{\mathrm{II}}(1,3-\right.$ pdta $\left.)\right] \cdot 2 \mathrm{H}_{2} \mathrm{O}(\mathrm{M}$ $=\quad \mathrm{Mg}[9], \quad \mathrm{Co} \quad[10,11], \quad \mathrm{Ni} \quad[12], \quad \mathrm{Cu} \quad[13,14] \quad$ and $\mathrm{Zn} \quad[15])$, $\left[\mathrm{M}^{, \mathrm{II}}\left(\mathrm{H}_{2} \mathrm{O}\right)_{6}\right]\left[\mathrm{M}^{\mathrm{II}}(1,3-\right.$ pdta $\left.)\left(\mathrm{H}_{2} \mathrm{O}\right)\right] \cdot 2 \mathrm{H}_{2} \mathrm{O}(\mathrm{M}=\mathrm{Mn}[16]$ and $\mathrm{Cd}[15,16])$, and $1 \mathrm{D}$ chain-like coordination polymers $\mathrm{Ca}_{2}\left(\mathrm{H}_{2} \mathrm{O}\right)_{6}\left[\left(\mathrm{Ca}_{2}(1,3-\text { pdta })_{2}\left(\mathrm{H}_{2} \mathrm{O}\right)_{2}\right] \cdot 4 \mathrm{H}_{2} \mathrm{O}\right.$ $\left[\mathrm{Ba}\left(1,3-\mathrm{H}_{2} \text { pdta }\right)\left(\mathrm{H}_{2} \mathrm{O}\right)_{3}\right]_{\mathrm{n}}$ [17], $\left[\mathrm{ZnBr}_{2}\left(1,3-\mathrm{H}_{4} \text { pdta }\right)\left(\mathrm{H}_{2} \mathrm{O}\right)\right]_{\mathrm{n}}[18]$ and La-1,3-pdta with MOF structures $[19,20]$ have been isolated using 1,3-pdta ligand. Quantum mechanical charge field molecular dynamics is also used for the structural and dynamic study of calcium ethylenediaminetetraacetate in solution [21]. However, less concern is related to the influence of $\mathrm{pH}$ value for the coordination ability and solution behavior [22,23]. Here a systematically $\mathrm{pH}$ dependent research gives different calcium 1,3-propylenediaminetetraacetates between $\mathrm{pH}$ $1.0 \sim 9.0$, which include two one dimensional complexes $\left[\mathrm{Ca}\left(1,3-\mathrm{H}_{4} \mathrm{pdta}\right)\left(\mathrm{NO}_{3}\right)_{2}\left(\mathrm{H}_{2} \mathrm{O}\right)_{2}\right]_{\mathrm{n}}(\mathbf{1})$ 
and $\mathrm{Ca}_{2}\left(\mathrm{H}_{2} \mathrm{O}\right)_{6}\left[\left(\mathrm{Ca}_{2}(1,3-\text { pdta })_{2}\left(\mathrm{H}_{2} \mathrm{O}\right)_{2}\right] \cdot 4 \mathrm{H}_{2} \mathrm{O}\right.$ (4) [9], one 3D metal organic framework $\left[\mathrm{Ca}\left(1,3-\mathrm{H}_{2} \mathrm{pdta}\right)\right]_{\mathrm{n}} \cdot \mathrm{nH}_{2} \mathrm{O}$ (2) and a $2 \mathrm{D}$ structure $\mathrm{K}_{4}\left[\mathrm{Ca}_{2}(1,3-\text { pdta })_{2}\right] \cdot 2 \mathrm{H}_{2} \mathrm{O} \cdot 2 \mathrm{CH}_{3} \mathrm{OH}$ (3) respectively. A free trimeric ligand $\left(1,3-\mathrm{H}_{4} \mathrm{pdta}\right)_{3}$ is also obtained for comparison.

\section{Experimental}

\subsection{Materials and physical techniques}

All chemical reagents were analytic grade. Elemental analyses $(\mathrm{C}, \mathrm{H}$ and $\mathrm{N})$ were performed on a Vario EL III CHN elemental analyzer, and the ammonium-N was determined by ion chromatography. IR spectra were recorded in the range $400 \sim 4000 \mathrm{~cm}^{-1}$ on a Nicolet FT-IR 330 spectrometer in KBr pellets. TG analyses were performed on a Netzsch SDT Q600 instrument in air atmosphere with a heating rate of $10{ }^{\circ} \mathrm{C} \cdot \mathrm{min}^{-1}$. Solution ${ }^{13} \mathrm{C}$ NMR spectra were recorded on a Bruker AV 400 NMR spectrometer with $\mathrm{D}_{2} \mathrm{O}$ using DSS (sodium 2,2-dimethyl-2-silapentane-5-sulfonate) as an internal reference.

\subsection{Synthesis of $\left[\mathrm{Ca}\left(1,3-\mathrm{H}_{4} \mathrm{pdta}\right)\left(\mathrm{NO}_{3}\right)_{2}\left(\mathrm{H}_{2} \mathrm{O}\right)_{2}\right]_{n}(\mathbf{1})$}

1,3-H4pdta (306 mg, $1.0 \mathrm{mmol})$ was dissolved in $5 \mathrm{~mL}$ water. A solution of $\mathrm{Ca}\left(\mathrm{NO}_{3}\right)_{2}$ (164 $\mathrm{mg}, 1.0 \mathrm{mmol}$ ) in $2 \mathrm{~mL}$ water was added to the above solution, and the $\mathrm{pH}$ value of the mixture was adjusted to 2.5 with $2.0 \mathrm{M} \mathrm{NaOH}$. The mixture was stirred for $15 \mathrm{~min}$ at room temperature and warmed at $80{ }^{\circ} \mathrm{C}$ for $18 \mathrm{~h}$. The solution was allowed to evaporate at room temperature. After one week, colorless bulk crystals of 1 were isolated with a yield of $246 \mathrm{mg}$ (48.6\%). Anal. calcd. for $\mathrm{C}_{11} \mathrm{H}_{22} \mathrm{~N}_{4} \mathrm{O}_{16} \mathrm{Ca}$ (Mr 506.40): C, 26.1; H, 4.3; N, 11.1; found: $\mathrm{C}$, 26.1; H, 3.7; N, 11.3. IR $\left(\mathrm{cm}^{-1}\right): 3432_{\mathrm{sb}}, 1726_{\mathrm{vw}}, 1634 \mathrm{~s}, 1408_{\mathrm{m}}, 1384_{\mathrm{s}}, 1260_{\mathrm{w}}, 1107_{\mathrm{w}}, 902_{\mathrm{w}}$, $802_{\mathrm{w}}, 618_{\mathrm{w}}$

\subsection{Synthesis of $\left[\mathrm{Ca}\left(1,3-\mathrm{H}_{2} \mathrm{pdta}\right)\right]_{n} \cdot n \mathrm{H}_{2} \mathrm{O}(2)$}

1,3-H4pdta (306 mg, $1.0 \mathrm{mmol})$ was dissolved in $5 \mathrm{~mL}$ water. A solution of $\mathrm{CaCl}_{2}(110$ $\mathrm{mg}, 1.0 \mathrm{mmol}$ ) in $2 \mathrm{~mL}$ water were added. The $\mathrm{pH}$ value was adjusted to $3.0 \sim 5.0$ with $2.0 \mathrm{M}$ $\mathrm{NaOH}$. The mixture was added with $10 \mathrm{~mL}$ methanol and stirred for $15 \mathrm{~min}$ at room 
temperature, and warmed at $80{ }^{\circ} \mathrm{C}$ for $18 \mathrm{~h}$. The solution was allowed to evaporate at room temperature. After one day, colorless acicular crystals of 2 were isolated with a yield of 125 mg (34.5\%). Anal. calcd. for $\mathrm{C}_{11} \mathrm{H}_{18} \mathrm{~N}_{2} \mathrm{O} 9 \mathrm{Ca}(\mathrm{Mr} 362.35)$ : C, 36.4; $\mathrm{H}, 5.0 ; \mathrm{N}, 7.7$; found: $\mathrm{C}$, 36.5; H, 5.1; N, 8.0. IR $\left(\mathrm{cm}^{-1}\right): 3450_{\mathrm{sb}}, 1633_{\mathrm{s}}, 1407_{\mathrm{s}}, 1364_{\mathrm{m}}, 1315_{\mathrm{w}}, 1119_{\mathrm{w}}, 920_{\mathrm{w}}, 887_{\mathrm{w}}, 710_{\mathrm{w}}$, $621_{\mathrm{w}}, 553_{\mathrm{w}}, 487_{\mathrm{w}}$.

\subsection{Synthesis of $\mathrm{K}_{4}\left[\mathrm{Ca}_{2}(1,3-p d t a)_{2}\right] \cdot 2 \mathrm{H}_{2} \mathrm{O} \cdot 2 \mathrm{CH}_{3} \mathrm{OH}(3)$}

1,3-H4pdta (306 mg, $1.0 \mathrm{mmol})$ and $\mathrm{CaCl}_{2}(110 \mathrm{mg}, 1.0 \mathrm{mmol})$ was dissolved in $1.0 \mathrm{~mL}$ water. The $\mathrm{pH}$ value of the mixture was adjusted to 9.0 with $2.0 \mathrm{M} \mathrm{KOH}$. The solution was added with $10 \mathrm{~mL}$ methanol and stirred for $15 \mathrm{~min}$ at room temperature, and warmed at $80{ }^{\circ} \mathrm{C}$ for $18 \mathrm{~h}$. The mixture was allowed to evaporate at room temperature. After one day, colorless bulk crystals of $\mathbf{1}$ were isolated with a yield of $67 \mathrm{mg}$ (14.2\%). Anal. calcd. for $\mathrm{C}_{24} \mathrm{H}_{40} \mathrm{~N}_{4} \mathrm{O}_{20} \mathrm{Ca}_{2} \mathrm{~K}_{4}$ (Mr 941.16): C, 30.6; H, 4.2; N, 6.0; found: $\mathrm{C}, 30.9 ; \mathrm{H}, 3.7 ; \mathrm{N}$, 5.7. IR $\left(\mathrm{cm}^{-1}\right): 3428_{\mathrm{sb}}, 2961_{\mathrm{w}}, 2845_{\mathrm{w}}, 1594_{\mathrm{s}}, 1415_{\mathrm{m}}, 1334_{\mathrm{w}}, 1288_{\mathrm{vw}}, 1263_{\mathrm{w}}, 1248_{\mathrm{w}}, 1171_{\mathrm{w}}, 1116_{\mathrm{w}}$, $1009_{\mathrm{w}}, 935_{\mathrm{w}}, 800_{\mathrm{w}}, 709_{\mathrm{w}}, 621_{\mathrm{w}}$.

\subsection{Synthesis of $\mathrm{Ca}_{2}\left(\mathrm{H}_{2} \mathrm{O}\right)_{6}\left[\left(\mathrm{Ca}_{2}(1,3-p d t a)_{2}\left(\mathrm{H}_{2} \mathrm{O}\right)_{2}\right] \cdot 4 \mathrm{H}_{2} \mathrm{O}\right.$ (4) [9].}

Compared with the previous report [9], preparation of 4 was improved as follow. 1,3-H4pdta (306 mg, $1.0 \mathrm{mmol})$ was dissolved in $5 \mathrm{~mL}$ water. A solution of $\mathrm{CaCl}_{2}(110 \mathrm{mg}$, $1.0 \mathrm{mmol}$ ) in $2 \mathrm{~mL}$ water was added. The $\mathrm{pH}$ value was adjusted to 7.0 with $2.0 \mathrm{M} \mathrm{NaOH}$. The mixture was stirred for $15 \mathrm{~min}$ at room temperature, and warmed at $80{ }^{\circ} \mathrm{C}$ for $18 \mathrm{~h}$. The solution was allowed to evaporate at room temperature. After one week, colorless bulk crystals of 4 were isolated with a yield of $107 \mathrm{mg}(43.6 \%)$.

\section{6. $X$-ray structural analyses}

Crystals with suitable sizes were sealed in capillaries. The X-ray diffraction data of $\mathbf{1}$ $\sim 3$ were collected on an Oxford CCD diffractometer with graphite monochromatic Mo-K $\alpha$ 
radiation $(\lambda=0.71073 \AA)$ at $173(2) \mathrm{K}$. Multi-scan absorption corrections were applied. The structures were solved with direct method and refined by full-matrix least squares on $\mathrm{F}^{2}$ using SHELXTL software package [24-26]. The hydrogen atoms on the carbon atoms were added theoretically. A summary of the crystallography data and refinements for $\mathbf{1} \sim \mathbf{3}$ are listed in Table 1. CCDC deposition numbers are 1451057 (1), 1450974 (2) and 1451001 (3) respectively.

In $\mathbf{1}$, the $\mathrm{H}$ atoms bound to water oxygen atoms were either located in difference Fourier maps or positioned to optimize the hydrogen bonding. All $\mathrm{O}-\mathrm{H}$ bond lengths were first restrained to $0.85 \AA$, but then kept fixed in the final least-squares cycles. These $\mathrm{H}$ atoms were assigned $\mathrm{U}_{\mathrm{iso}}(\mathrm{H})=1.5 \mathrm{U}_{\text {eq }}(\mathrm{O})$. Despite many attempts, one of the two hydrogen atoms bound to $\mathrm{O} 1 \mathrm{w}$ is difficult to be located. Hence, one $\mathrm{H}$-atom bound to $\mathrm{O} 1 \mathrm{w}$ is absent in the structure deposited to the CSD. The $\mathrm{H} 2 \mathrm{w}$ bound to $\mathrm{O} 2 \mathrm{w}$ was fixed in a $2.15 \AA$ distance with $\mathrm{O} 2$ to make the angle of $\mathrm{H} 2 \mathrm{w}-\mathrm{O} 2 \mathrm{w}-\mathrm{H} 2 \mathrm{wa}$ around $105^{\circ}$. The $\mathrm{H}$ atoms of the $-\mathrm{COOH}$ groups were placed in geometrically calculated positions and refined using a riding model with $\mathrm{O}-\mathrm{H}$ $=0.85 \AA$ and $\mathrm{U}_{\text {iso }}(\mathrm{H})=1.5 \mathrm{U}_{\text {eq }}(\mathrm{O})$. In 2 , the $\mathrm{H}$ atoms bound to water oxygen atoms were placed in geometrically calculated positions and refined using a riding model with $\mathrm{O}-\mathrm{H}=$ $0.85 \AA$ and $\mathrm{U}_{\mathrm{iso}}(\mathrm{H})=1.5 \mathrm{U}_{\mathrm{eq}}(\mathrm{O})$. In 3 , the $\mathrm{H}$ atoms bound to water oxygen atoms were either located in difference Fourier maps or positioned to optimize the hydrogen bonding, with $\mathrm{O}-\mathrm{H}$ $=0.85 \AA, \mathrm{H} \cdots \mathrm{H}$ distance $=1.39 \AA$ and $\mathrm{U}_{\mathrm{iso}}(\mathrm{H})=1.5 \mathrm{U}_{\mathrm{eq}}(\mathrm{O})$. The H1wb bound to $\mathrm{O} 1 \mathrm{w}$ was fixed in a $2.00 \AA$ distance with $\mathrm{O} 2$ to optimize the hydrogen bonding. The hydrogen atom of hydroxy group in methanol were firstly found in a difference Fourier map and then fixed with an O9-H9 distance with $0.98 \AA$, a H9 $\cdots$ H1wb distance of $2.20 \AA$ and a metal $\cdots \mathrm{H} 9$ distance of $3.40 \AA$ to optimize the hydrogen bonding. The $\mathrm{H}$ atom was assigned $\mathrm{U}_{\text {iso }}(\mathrm{H})=1.5 \mathrm{U}_{\text {eq }}(\mathrm{O})$.

[Table 1]

\section{Results and discussion}


In the synthesis, the determining factor is $\mathrm{pH}$ value of the solution which influences the formations of different products. When the $\mathrm{pH}$ value is lower than $2,1,3-\mathrm{H}_{4}$ pdta will not coordinate with calcium ions so as to separate out as acicular crystal which comprises three $1,3-\mathrm{H}_{4} \mathrm{pdta}$ in each unit cell. When the $\mathrm{pH}$ value is increased to 2.5 , two of the four carboxy groups are deprotonated and coordinated strongly with calcium ions, the charge is balanced by nitrates for 1 . When the $\mathrm{pH}$ value is in the range of $3.0 \sim 5.0$, the nitrogen atoms are still protonated and do not coordinate with calcium ions, but the four carboxy groups are all deprotonated and chelate to calcium ions to construct 2. Furthermore, all carboxy groups and nitrogen atoms are deprotonated in neutral solution, and form a chelate in which 1,3-pdta acts as a hexadentate ligand in $\mathbf{3}$. The redundant calcium ions act as cations to balance the charge and bridge the chelate rings forming the complex $\mathrm{Ca}_{2}\left(\mathrm{H}_{2} \mathrm{O}\right)_{6}\left[\left(\mathrm{Ca}_{2}(1,3-\mathrm{pdta})_{2}\left(\mathrm{H}_{2} \mathrm{O}\right)_{2}\right] \cdot 4 \mathrm{H}_{2} \mathrm{O}(4)\right.$ [9]. If the postassium ions are excess in an alkaline environment, postassium ions will replace the calcium ions as cations. The chelating capabilities of the carboxy groups are enhanced and the calcium ions are connected by the adjacent chelate rings. The different products at different $\mathrm{pH}$ values are shown in Scheme 1. All complexes are soluble in water like anticoagulants of $\mathrm{H}_{4}$ edta.

[Scheme 1]

\subsection{Crystal structures of $\mathbf{1} \sim \mathbf{3}$}

\subsubsection{Structure of $\left[\mathrm{Ca}\left(1,3-\mathrm{H}_{4} \mathrm{pdta}\right)\left(\mathrm{NO}_{3}\right)_{2}\left(\mathrm{H}_{2} \mathrm{O}\right)_{2}\right]_{n}(\mathbf{1})$}

Structure of $\left[\mathrm{Ca}\left(1,3-\mathrm{H}_{4} \text { pdta }\right)\left(\mathrm{NO}_{3}\right)_{2}\left(\mathrm{H}_{2} \mathrm{O}\right)_{2}\right]_{\mathrm{n}}$ (1) comprises one-dimensional chain in which adjacent calcium atoms are bridged by carboxy oxygen atoms from 1,3-pdta (Figure 1). The coordination environment of calcium ion is fulfilled by four nitrate oxygen atoms, two carboxy oxygen atoms and two water molecules which formed a $\mathrm{CaO}_{8}$ polyhedron. The coordination number is eight. Each 1,3-pdta ligand connects two calcium ions bidentately 
with $\mathrm{O} 1$ and O1a, forming an infinite chain (Figure S1). There exist four strong intramolecular hydrogen bonds in $\mathbf{1}$ [dashed bond in Figure 1, N1 $\cdots \mathrm{O} 1$ and $\mathrm{N} 1 \mathrm{a} \cdots \mathrm{O} 1 \mathrm{a} 2.600(4)$

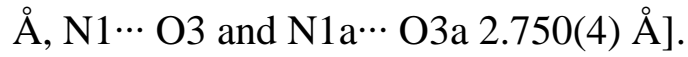

[Figure 1]

\subsubsection{Structure of $\left[\mathrm{Ca}\left(1,3-\mathrm{H}_{2} \mathrm{pdta}\right)\right]_{n} \cdot n \mathrm{H}_{2} \mathrm{O}(2)$}

Structure of $\left[\mathrm{Ca}\left(1,3-\mathrm{H}_{2} \text { pdta }\right)\right]_{n} \cdot \mathrm{nH}_{2} \mathrm{O}$ (2) comprises a three-dimensional polymeric network in which adjacent calcium atoms are bridged by 1,3- $\mathrm{H}_{2}$ pdta ligands (Figure 2a). The basic unit is a mononuclear structure which contains one calcium ion and one $1,3-\mathrm{H}_{2} \mathrm{pdta}$. The $\mathrm{Ca}(1)$ center is octa-coordinated which satisfied by eight carboxy oxygen atoms from five different $1,3-\mathrm{H}_{2}$ pdta, forming a $\mathrm{CaO}_{8}$ polyhedron. In the view parallel with $a b$ plane, each 1,3- $\mathrm{H}_{2}$ pdta uses its four oxygen atoms from two symmetry related carboxy groups [O3-C3-O4 and $\mathrm{O} 3 \mathrm{a}-\mathrm{C} 3 \mathrm{a}-\mathrm{O} 4 \mathrm{a}]$ to chelate one $\mathrm{Ca}(\mathrm{II})$ ion. The other two carboxy oxygen atoms $[\mathrm{O}(1)$ and $\mathrm{O}(1 \mathrm{a})]$ are connected with $\mathrm{Ca}(\mathrm{II})$ ions related by unit translation along $a$ axis, which extend a 2D layer structure as shown in Figure 2b. Adjacent $\mathrm{CaO}_{8}$ polyhedrons are shared by two carboxylate oxygen atoms and form zigzag chains running along the $c$ axis. Furthermore, the $\mathrm{Ca}(\mathrm{II})$ ion is coordinated with $\mathrm{O} 4 \mathrm{~d}$ and O4e [Symmetry codes: $d(2-x, 1-y$, $1-z), e(x, 1-y,-1 / 2+z)]$ from the other $\mathrm{CaO}_{8}$ polyhedrons, which are from the adjacent layers along the $c$ axis to complete 3D MOF structure (Figure S2a in Supporting information).

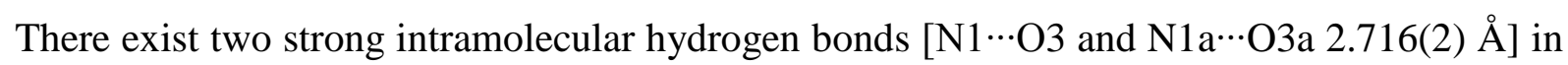
2. The crystallized water molecule in $\mathbf{2}$ is fixed by four hydrogen bonds [O $1 \mathrm{w} \cdots \mathrm{O} 1$, $\mathrm{O} 1 \mathrm{w} \cdots \mathrm{O} 1 \mathrm{~b} 2.960(3) \AA$ and $\mathrm{O} 1 \mathrm{w} \cdots \mathrm{O} 2, \mathrm{O} 1 \mathrm{w} \cdots \mathrm{O} 2 \mathrm{~b} 3.363(2) \AA$ in Figure S2b].

[Figures $2 \mathrm{a}$ and $2 \mathrm{~b}$ ]

\subsubsection{Structure of $\mathrm{K}_{4}\left[\mathrm{Ca}_{2}(1,3-p d t a)_{2}\right] \cdot 2 \mathrm{H}_{2} \mathrm{O} \cdot 2 \mathrm{CH}_{3} \mathrm{OH}(3)$}


$\mathrm{K}_{4}\left[\mathrm{Ca}_{2}(1,3-\text { pdta })_{2}\right] \cdot 2 \mathrm{H}_{2} \mathrm{O} \cdot 2 \mathrm{CH}_{3} \mathrm{OH}(3)$ forms a $2 \mathrm{D}$ structure. Each asymmetric unit comprises a mononuclear chelated unit which contains two potassium ions, calcium ion, 1,3-pdta and solvent molecules. $\mathrm{Ca}(\mathrm{II})$ ion exists in hepta-dentate coordination environment. Two nitrogen atoms and four oxygen atoms from one 1,3-pdta chelate to $\mathrm{Ca}$ (II) ion in a mononuclear unit. Unlike the dimeric anion $\left[\mathrm{Ca}_{2}(1,3-\text { pdta })_{2}\left(\mathrm{H}_{2} \mathrm{O}\right)_{2}\right]^{4-}$ connected by water molecules [9], two mononuclear $[\mathrm{Ca}(1,3-\text { pdta })]^{2-}$ chelated units are connected to each other by $\mathrm{Ca}(1)-\mathrm{O}(7 \mathrm{a})$ and $\mathrm{Ca}(1 \mathrm{a})-\mathrm{O}(7)$ to make up a dimeric unit as shown in Figure 3 . The potassium ions $[K(1)$ and $K(2)]$ coordinate to the oxygen atoms from carboxy groups, and $K(2)$ coordinates additionally to two symmetry related oxygen atoms of methanol, thus forming a 2D structure parallel to the (100) lattice plane as showed in Figure S3a. K(1) coordinate to six carboxy oxygen atoms $\mathrm{O}(5), \mathrm{O}(3 \mathrm{a})$, and $\mathrm{O}(8 \mathrm{a})$ from the same dimeric unit and $\mathrm{O}(4 \mathrm{~b}), \mathrm{O}(6 \mathrm{c})$ and $\mathrm{O}(8 \mathrm{~d})$ from the other two dimeric units. The coordination number of $\mathrm{K}(1)$ is six. $\mathrm{K}(2)$ is fulfilled by four carboxy oxygen atoms from three dimeric units and two hydroxy oxygen atoms of methanol. That is coordinated by $\mathrm{O}(1)$ and $\mathrm{O}(8 \mathrm{a})$ from the same dimeric unit, $\mathrm{O}(6 \mathrm{c})$ and $\mathrm{O}(6 \mathrm{e})$ from the other two dimeric units and two symmetry related oxygen atoms of methanol $[\mathrm{O}(9)$ and $\mathrm{O}(9 \mathrm{f})]$. The coordination environments of $\mathrm{K}(1)$ and $\mathrm{K}(2)$ are showed in Figure S3b. Finally, $\mathrm{K}(1)$ and $\mathrm{K}(2)$ connect the four symmetry related dimeric units in $b c$ plane forming a $2 \mathrm{D}$ structure. The oxygen atom $[\mathrm{O}(9)]$ of methanol serves as a bridge between potassium ions $[\mathrm{K}(2)]$. The water molecule $\mathrm{O} 1 \mathrm{w}$ correlates the adjacent layers by

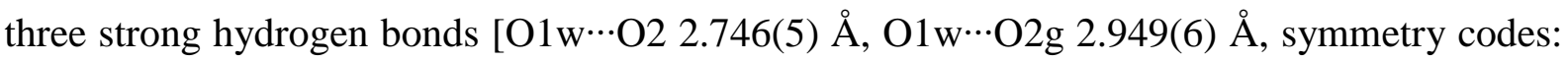

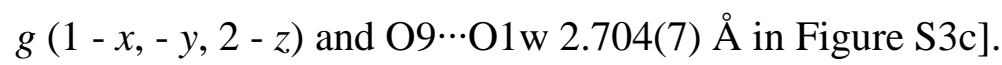

[Figure 3]

\subsubsection{Comparisions of bond distances.}

Table 2 shows the comparisons of bond distances in calcium 
ethylenediaminetetraacetates and propylenediaminetetraacetates. 1 possesses the strongest $\mathrm{Ca}-\mathrm{O}_{\text {carboxy }}$ bond which is attributed to the less space steric hindrance. With the increase of coordination number, the bond distances of $\mathrm{Ca}-\mathrm{O}_{\text {carboxy }}$ are weakened for $\mathbf{3}$ and $\mathbf{4}$. It seems that calcium-pdta is much compact than those of calcium-edta based on bond distances. This is attributed to the flexible propylenediamine chain in the ligand.

[Table 2]

\subsection{Thermal properties}

Thermal data of $\mathbf{1} \sim \mathbf{3}$ are listed in Table S1. TG curves are showed in Figure S4. Thermal decompositions of three complexes can be divided into two stages. The first stage corresponds to the release of methanol, water molecules and nitrate ions. In the second stage, the ligands in the complexes decompose and transform into calcium oxides.

\subsection{IR spectra}

IR spectra for $1 \sim 3$ are presented in Figure 4 . The bands at $1634 \sim 1595 \mathrm{~cm}^{-1}$ and $1415 \sim 1407 \mathrm{~cm}^{-1}$ are attributed to asymmetric and symmetric vibrations of carboxy groups of 1,3-pdta ligand. Compared with free carboxylic acidic group $\left(1740 \sim 1700 \mathrm{~cm}^{-1}\right)$, the absorption peaks are red shifts due to the coordination of carboxy group with calcium atom, which reduces the bond strength of $\mathrm{C}-\mathrm{O}$ bond. It is notable there is a weak peak at $1726 \mathrm{~cm}^{-1}$ for $\mathbf{1}$ which can be attributed to uncoordinated carboxylic acidic group from 1,3-H4pdta. Due to the tanglesome coordination modes, the asymmetric stretching band $v_{a s}\left(\mathrm{CO}_{2}\right)$ for 2 splits into two peaks attributed to $\mathrm{O}(1)-\mathrm{C}(1)-\mathrm{O}(2)$ and $\mathrm{O}(3)-\mathrm{C}(3)-\mathrm{O}(4)$ (Figure 2a) respectively. While the asymmetric and symmetric vibrations $v_{\text {as }}\left(\mathrm{CO}_{2}\right)$ for $\mathbf{3}$ show only one peak because of the higher symmetry in the structure. Besides, there are three weak peaks at 2961, 2845, and $1116 \mathrm{~cm}^{-1}$ for $\mathbf{3}$, which can be attributed to methanol molecules. Comparing with free methanol $\left(2945 \mathrm{~cm}^{-1}, 2833 \mathrm{~cm}^{-1}\right.$ and $\left.1030 \mathrm{~cm}^{-1}\right)$, the blue shifts for the three peaks of the 
crystallized methanol suggest that methanol have been activated in 3. Additionally, the bands centered at ca. $3400 \mathrm{~cm}^{-1}$ in $\mathbf{1} \sim \mathbf{3}$ are a characteristic peak for $\mathrm{O}-\mathrm{H}$ bonds.

[Figure 4]

\subsection{NMR Analyses}

Solution ${ }^{13} \mathrm{C}$ NMR and ${ }^{1} \mathrm{H}$ NMR spectra of 1,3-pdta and $\mathbf{1} \sim \mathbf{3}$ are given in Figure 5, Figures S5 and S6, which supply more message for the chemical environments of $-\mathrm{CO}_{2}$, $-\mathrm{CH}_{2} \mathrm{CO}_{2},-\mathrm{CH}_{2} \mathrm{~N},-\mathrm{CH}_{2}$ - and $\mathrm{CH}_{3} \mathrm{OH}$ groups. The chemical shifts values are listed in Table 3 and Table S2.

[Figure 5] and [Table 3]

${ }^{13} \mathrm{C}$ NMR signals for $\mathbf{1}$ are similar with $1,3-\mathrm{H}_{4}$ pdta in the $\mathrm{D}_{2} \mathrm{O}$, which shows that $\mathbf{1}$ dissociates into calcium ions and 1,3- $\mathrm{H}_{4}$ pdta after dissolution. The ${ }^{13} \mathrm{C}$ NMR signals for 2 show small downfield shifts compared with those of $1,3-\mathrm{H}_{4}$ pdta in $\mathrm{D}_{2} \mathrm{O}$. It may be caused by the weakly interaction between calcium ions and 1,3- $\mathrm{H}_{4}$ pdta in the solution. The inconspicuous highfield shift of the $-\mathrm{CH}_{2} \mathrm{~N}$ group indicated that the nitrogen atoms are protonated in the solution.

Compared with 1,3-H4pdta, obvious downfield shifts show the coordination of 1,3-pdta ligands in 3. Only one set of ${ }^{13} \mathrm{C}$ NMR chemical shift data are observed for $\mathbf{3}$. All carboxy groups give only one ${ }^{13} \mathrm{C}$ NMR signal at $182.47 \mathrm{ppm}(\Delta \delta=10.57 \mathrm{ppm})$ and one $-\mathrm{CH}_{2} \mathrm{CO}_{2}$ signal at $64.80 \mathrm{ppm}(\Delta \delta=5.99 \mathrm{ppm})$. Large downfield shifts are observed. From the molecular structure in the solid state, there are two kinds of carboxy groups, but only one peak is observed for the carboxy groups in solution. This should be the result from the dissociation of less strongly bridged carboxy group, and the formation of a monomeric species after dissolution as following, where monomeric calcium 
propylenediaminetetraacetate hydrate has been proposed as a dominant species in solution $[22]$.

$$
\mathrm{K}_{4 \mathrm{n}}\left[\mathrm{Ca}_{2}(1,3-\mathrm{pdta})_{2}\right]_{\mathrm{n}} \leftrightarrows 2 \mathrm{n}\left[\mathrm{Ca}(1,3-\mathrm{pdta})\left(\mathrm{H}_{2} \mathrm{O}\right)\right]^{2-}+4 \mathrm{nK}^{+}
$$

There is also only one set of signals for $-\mathrm{CH}_{2} \mathrm{~N}-(64.28 \mathrm{ppm}, \Delta \delta=8.40 \mathrm{ppm})$ and $-\mathrm{CH}_{2}-(26.00 \mathrm{ppm}, \Delta \delta=3.78 \mathrm{ppm})$. All in all, the bridged carboxy groups of 1,3-pdta in the dimeric calcium complexes must dissociate to give a monomeric unit. This is also supported by ${ }^{1} \mathrm{H}$ NMR spectrum which has three signals at $3.34 \mathrm{ppm}(\Delta \delta=0.72 \mathrm{ppm}), 3.08 \mathrm{ppm}(\Delta \delta=$ $0.35 \mathrm{ppm})$ and $2.59 \mathrm{ppm}(\Delta \delta=-0.34 \mathrm{ppm})$ for $-\mathrm{CH}_{2} \mathrm{CO}_{2},-\mathrm{CH}_{2} \mathrm{~N}$ and $-\mathrm{CH}_{2-}$ groups respectively.

Additionally, the methyl group in methanol give a ${ }^{13} \mathrm{C}$ NMR signal at $51.59 \mathrm{ppm}(\Delta \delta=$ $2.09 \mathrm{ppm})$. The downfield shift suggested that methanol molecule is still coordinated with potassium ion in the solution. However, the ${ }^{1} \mathrm{H}$ NMR signal for $\mathrm{CH}_{3}$ - is overlap with $-\mathrm{CH}_{2} \mathrm{~N}$ group at $3.34 \mathrm{ppm}$, showing downfield shift of methyl group after interaction with potassium cation.

\section{Conclusions}

In summary, four novel calcium 1,3-propanediaminetetraacetates have been isolated from the reactions of calcium salt with 1,3-pdta ligand between $\mathrm{pH} 2.5 \sim 9.0$. The synthetic routes indicated that 1,3-pdta may coordinate to calcium ions in various types which depended on the $\mathrm{pH}$ value variations. The different acidity can change the protons in 1,3-pdta and further impact the coordination ability for the formations of 1D chains, 2D or 3D network structures. The minimum coordination number is 2 in $\left[\mathrm{Ca}\left(1,3-\mathrm{H}_{4} \mathrm{pdta}\right)\left(\mathrm{NO}_{3}\right)_{2}\left(\mathrm{H}_{2} \mathrm{O}\right)_{2}\right]_{\mathrm{n}}(\mathbf{1})$. Moreover, monomeric chelate of calcium hydrate propylenediaminetetraacetate $\left[\mathrm{Ca}(1,3-\text { pdta })\left(\mathrm{H}_{2} \mathrm{O}\right)\right]^{2-}$ is proposed as a dominant species in neutral and weak basic solution, 
which should be related to the form of calcium ethylenediaminetetraacetate in physiological condition [6,7].

\section{Appendix A. Supplementary data}

Supplementary data related to this article can be found at Doi

\section{Acknowledgements}

We thank the National Science Foundation of Fujian (No. 2016I0012) and the Research Fund of the Central Universities (No.20720150041) for their generous financial supports. 


\section{References}

[1] A. Torvisco, A.Y. O'Brien, K. Ruhlandt-Senge, Coord. Chem. Rev. 255 (2011) 1268.

[2] J. Burgess, E. Raven, Calcium in Biological Systems, in: R. VanEldik, C.D. Hubbard (Eds.) Advances In Inorganic Chemistry, Vol 61: Metal Ion Controlled Reactivity, Elsevier Academic Press Inc, San Diego, 2009, pp. 251.

[3] R.B. Martin, Metal Ions in Biological Systems 17 (1984) 1.

[4] S.L. Diamond, J. Thromb. Haemost. 11 (2013) 224.

[5] J.W.M. Heemskerk, N.J.A. Mattheij, J. Cosemans, J. Thromb. Haemost. 11 (2013) 2.

[6] T. Raczat, L. Kraemer, C. Gall, D.R. Weiss, R. Eckstein, J. Ringwald, Vox Sang. 107 (2014) 196.

[7] T. Barri, L.O. Dragsted, Anal. Chim. Acta 768 (2013) 118.

[8] A.F.W. Holleman, E., Inorganic Chemistry, San Diego: Academic Press, 2001.

[9] D.D. Radanović, U. Rychlewska, M.I. Djuran, B. Warżajtis, N.S. Drašković, D.M. Gurešić, Polyhedron 23 (2004) 2183.

[10] D.D. Radanović, U. Rychlewska, M.I. Djuran, N.S. Drašković, M.M. Vasojević, I.M. Hodžić, D.J. Radanović, Polyhedron 22 (2003) 2745.

[11] N.S. Draskovic, M.I. Djuran, M.S. Cvijovic, D.D. Radanovic, V. Jevtovic, Transit. Met. Chem. 29 (2004) 874.

[12] S. Belošević, M.M. Vasojević, M.S. Jeremić, A. Meetsma, Z.D. Matović, J. Coord. Chem. 66 (2013) 1730.

[13] U. Rychlewska, D.D. Radanovic, V.S. Jevtovic, D.J. Radanovic, Polyhedron 19 (2000) 1. [14] M. Hernandez-Padilla, E. Chinea, S. Dominguez, A. Mederos, M.C. Munoz, F. Lloret, Polyhedron 19 (2000) 1175.

[15] U. Rychlewska, D.M. Gurešić, B. Warżajtis, D.D. Radanović, M.I. Djuran, Polyhedron 24 (2005) 2009.

[16] U. Rychlewska, B. Warżajtis, D. Cvetić, D.D. Radanović, D.M. Gurešić, M.I. Djuran, Polyhedron 26 (2007) 1717.

[17] M.L. Chen, Y.H. Hou, W.S. Xia, Z.H. Zhou, J. Coord. Chem. 66 (2013) 1906.

[18] M.L. Chen, F. Yang, Z.H. Zhou, Polyhedron 47 (2012) 60.

[19] M.L. Chen, Y.C. Guo, F. Yang, J.X. Liang, Z.X. Cao, Z.H. Zhou, Dalton Trans. 43 (2014) 6026.

[20] U. Rychlewska, B. Warżajtis, D.D. Radanović, N.S. Drašković, I.M. Stanojević, M.I. Djuran, Polyhedron 30 (2011) 983.

[21] S. Aime, R. Gobetto, R. Nano, E. Santucci, Inorg. Chim. Acta 129 (1987) L23.

[22] A.O. Tirler, T.S. Hofer, J. Phys. Chem. B 119 (2015) 8613.

[23] S. Han, E, Mathias, Y. Ba, J. Chem. 1 (2007) 1.

[24] G.M. Sheldrick, Acta Crystallogr. Sect. A 64 (2008) 112.

[25] L.J. Farrugia, Journal of Applied Crystallography 45 (2012) 849.

[26] O.V. Dolomanov, L.J. Bourhis, R.J. Gildea, J.A.K. Howard, H. Puschmann, J. Appl. Crystallogr. 42 (2009) 339.

[27] B.L. Barnett, V.A. Uchtman, Inorg. Chem. 18 (1979) 2674.

[28] M.I. Arriortua, M. Insausti, M.K. Urtiaga, J. Via, T. Rojo, Acta Crystallogr. Sect. C-Cryst. Struct. Commun. 48 (1992) 779.

[29] A.S. Antsyshkina, G.G. Sadikov, A.L. Poznyak, V.S. Sergienko, Russ. J. Inorg. Chem. 47 (2002) 39.

[30] M. Zabel, A.L. Poznyak, V.I. Pawlowski, J. Struct. Chem. 47 (2006) 581. 


\section{Figure and Table options}

Scheme 1. Calcium 1,3-propylenediaminetetraacetates at different $\mathrm{pH}$ values.

Figure 1. Structural diagram of $\left[\mathrm{Ca}\left(1,3-\mathrm{H}_{4} \text { pdta }\right)\left(\mathrm{NO}_{3}\right)_{2}\left(\mathrm{H}_{2} \mathrm{O}\right)_{2}\right]_{\mathrm{n}}(\mathbf{1})$. Symmetry codes: $a$ $(1-x, y, z), b(-x, y, z)$.

Figure 2a. Structural diagram of $\left[\mathrm{Ca}\left(1,3-\mathrm{H}_{2} \mathrm{pdta}\right)\right]_{\mathrm{n}} \cdot \mathrm{nH}_{2} \mathrm{O}(2)$. Symmetry codes: $a(2-x, y$, $1 / 2-z), b(1 / 2+x, 1 / 2+y, z), c\left(1 \frac{1 / 2}{2} x, 1 / 2+y, 1 / 2-z\right), d(2-x, 1-y, 1-z), \mathrm{e}(x$, $1-y,-1 / 2+z)$

Figure 2b. The 2D layer of $\left[\mathrm{Ca}\left(1,3-\mathrm{H}_{2} \mathrm{pdta}\right)\right]_{\mathrm{n}} \cdot \mathrm{nH}_{2} \mathrm{O}(2)$ paralleled to $a b$ plane.

Figure 3. Anion structure in $\mathrm{K}_{4}\left[\mathrm{Ca}_{2}(1,3 \text {-pdta })_{2}\right] \cdot 2 \mathrm{H}_{2} \mathrm{O} \cdot 2 \mathrm{CH}_{3} \mathrm{OH}(3)$. Symmetry codes: $a$ $(2-x,-y, 1-z)$

Figure 4. IR spectra of $\left[\mathrm{Ca}\left(1,3-\mathrm{H}_{4} \text { pdta }\right)\left(\mathrm{NO}_{3}\right)_{2}\left(\mathrm{H}_{2} \mathrm{O}\right)_{2}\right]_{\mathrm{n}}(\mathbf{1}),\left[\mathrm{Ca}\left(1,3-\mathrm{H}_{2} \mathrm{pdta}\right)\right]_{\mathrm{n}} \cdot \mathrm{nH}_{2} \mathrm{O}(\mathbf{2})$ and $\mathrm{K}_{4}\left[\mathrm{Ca}_{2}(1,3-\text { pdta })_{2}\right] \cdot 2 \mathrm{H}_{2} \mathrm{O} \cdot 2 \mathrm{CH}_{3} \mathrm{OH}(3)$.

Figure 5. Solution ${ }^{13} \mathrm{C}$ NMR spectra of $\left[\mathrm{Ca}\left(1,3-\mathrm{H}_{4} \text { pdta }\right)\left(\mathrm{NO}_{3}\right)_{2}\left(\mathrm{H}_{2} \mathrm{O}\right)_{2}\right]_{\mathrm{n}}(\mathbf{1})$, $\left[\mathrm{Ca}\left(1,3-\mathrm{H}_{2} \text { pdta }\right)\right]_{n} \cdot \mathrm{nH}_{2} \mathrm{O}(\mathbf{2}), \mathrm{K}_{4}\left[\mathrm{Ca}_{2}(1,3-\text { pdta })_{2}\right] \cdot 2 \mathrm{H}_{2} \mathrm{O} \cdot 2 \mathrm{CH}_{3} \mathrm{OH}(\mathbf{3})$ and $1,3-\mathrm{H}_{4}$ pdta in $\mathrm{D}_{2} \mathrm{O}$, DSS was used as an internal reference.

Table 1. Crystallographic data and refinements for $\left[\mathrm{Ca}\left(1,3-\mathrm{H}_{4} \mathrm{pdta}\right)\left(\mathrm{NO}_{3}\right)_{2}\left(\mathrm{H}_{2} \mathrm{O}\right)_{2}\right]_{\mathrm{n}}(\mathbf{1})$, $\left[\mathrm{Ca}\left(1,3-\mathrm{H}_{2} \text { pdta }\right)\right]_{n} \cdot \mathrm{nH}_{2} \mathrm{O}(2)$ and $\mathrm{K}_{4}\left[\mathrm{Ca}_{2}(1,3-\text { pdta })_{2}\right] \cdot 2 \mathrm{H}_{2} \mathrm{O} \cdot 2 \mathrm{CH}_{3} \mathrm{OH}(3)$.

Table 2. $\quad$ Comparisons of the selected bond distances $(\AA)$, coordination number (C.N.) of calcium ion and dentate number (D.N.) of 1,3-pdta (or edta) for $\left[\mathrm{Ca}\left(1,3-\mathrm{H}_{4} \text { pdta }\right)\left(\mathrm{NO}_{3}\right)_{2}\left(\mathrm{H}_{2} \mathrm{O}\right)_{2}\right]_{\mathrm{n}}(\mathbf{1}),\left[\mathrm{Ca}\left(1,3-\mathrm{H}_{2} \text { pdta }\right)\right]_{\mathrm{n}} \cdot \mathrm{nH}_{2} \mathrm{O}(\mathbf{2})$ and $\mathrm{K}_{4}\left[\mathrm{Ca}_{2}(1,3-\text { pdta })_{2}\right] \cdot 2 \mathrm{H}_{2} \mathrm{O} \cdot 2 \mathrm{CH}_{3} \mathrm{OH}(3)$, $\mathrm{Ca}_{2}\left(\mathrm{H}_{2} \mathrm{O}\right)_{6}\left[\left(\mathrm{Ca}_{2}(1,3-\text { pdta })_{2}\left(\mathrm{H}_{2} \mathrm{O}\right)_{2}\right] \cdot 4 \mathrm{H}_{2} \mathrm{O}\right.$ (4) [9] , $\mathrm{Ca}\left(\mathrm{H}_{2} \mathrm{O}\right)_{2}\left[\mathrm{Ca}\left(\right.\right.$ edta) $\left.\left(\mathrm{H}_{2} \mathrm{O}\right)\right] \cdot 4 \mathrm{H}_{2} \mathrm{O}(5)$ [27], $\mathrm{Sr}\left(\mathrm{H}_{2} \mathrm{O}\right)_{3}\left[\mathrm{Ca}(\right.$ edta $\left.)\left(\mathrm{H}_{2} \mathrm{O}\right)\right] \cdot \mathrm{H}_{2} \mathrm{O}(\mathbf{6})$ [28], [Ni(phen $\left.)_{3}\right]\left[\mathrm{Ca}(\right.$ edta $\left.)\left(\mathrm{H}_{2} \mathrm{O}\right)_{2}\right] \cdot 10.5 \mathrm{H}_{2} \mathrm{O}(7)[29],\left[\mathrm{Ca}\left(\mathrm{H}_{2}\right.\right.$ edta $\left.)\left(\mathrm{H}_{2} \mathrm{O}\right)\right] \cdot \mathrm{H}_{2} \mathrm{O}$ (8) [30].

Table 3. Solution ${ }^{13} \mathrm{C}$ NMR spectral data (in ppm) of 1,3-H 4 pdta, 1, 2 and 3. 

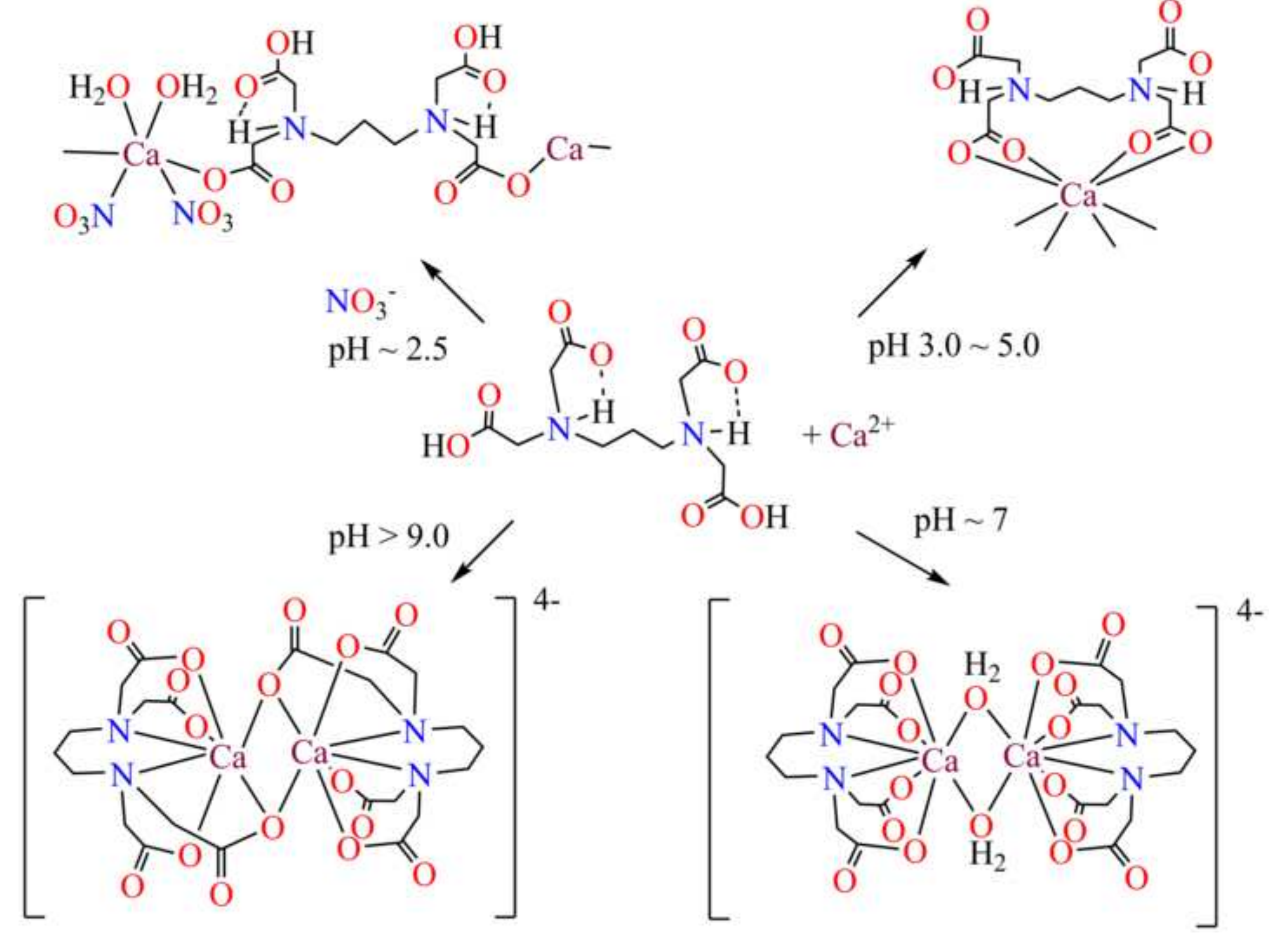

$\mathrm{pH}>9.0$
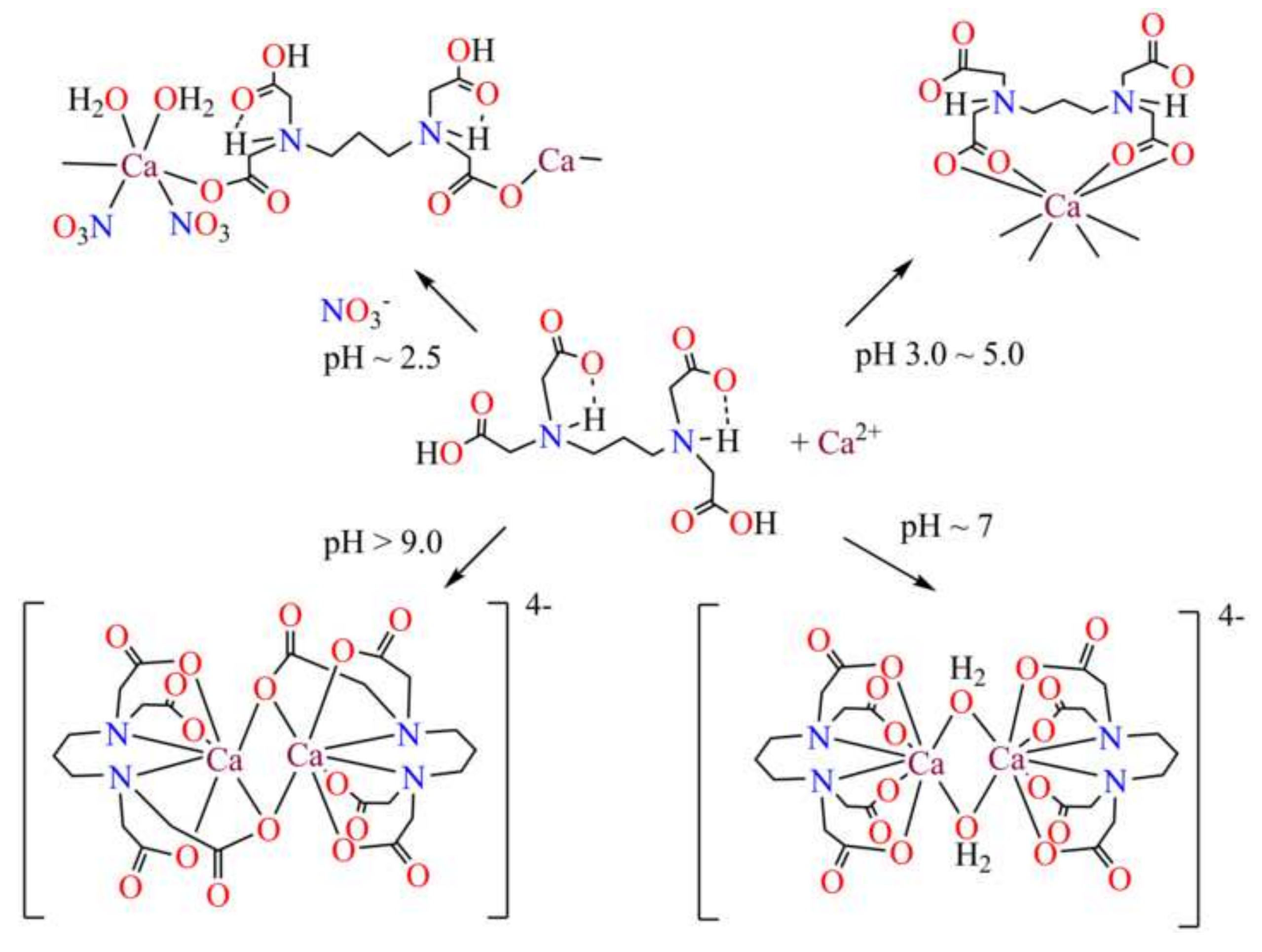

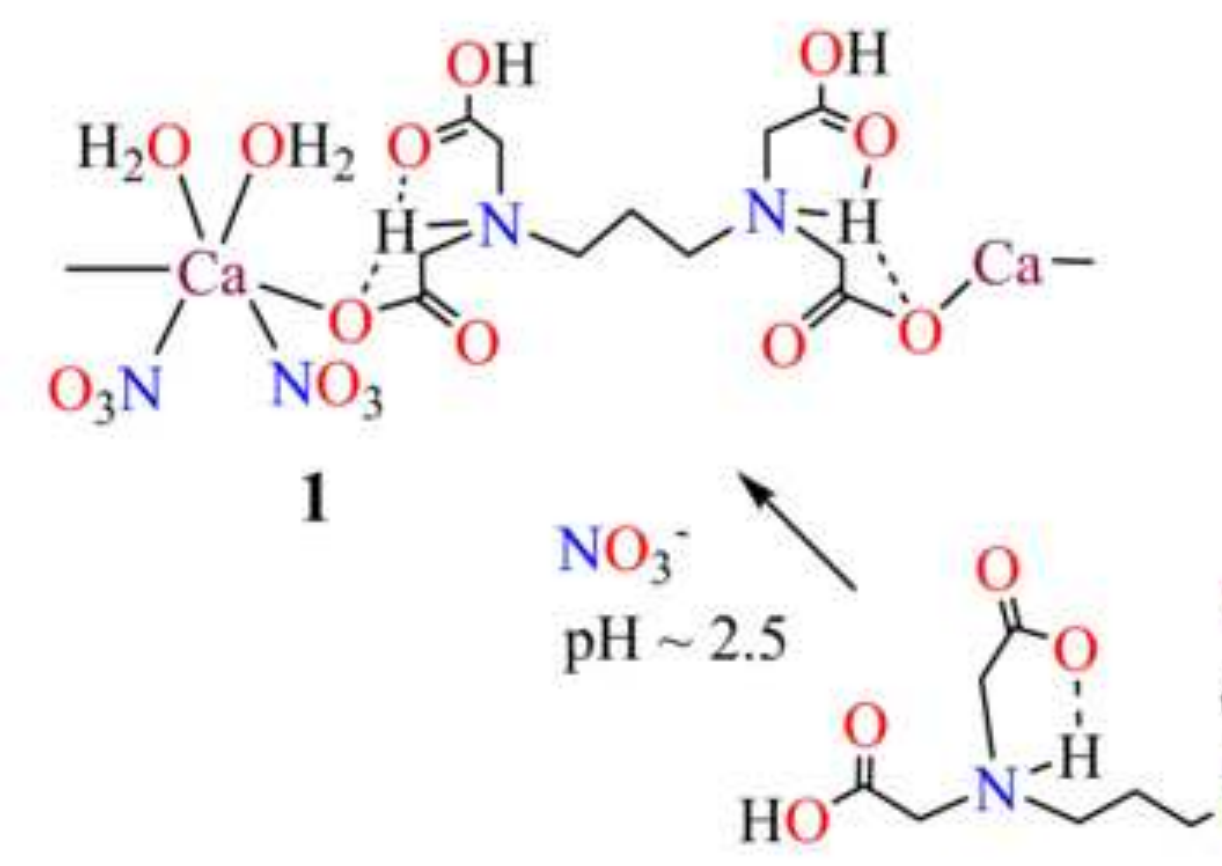

$$
\mathrm{pH}>9.0
$$
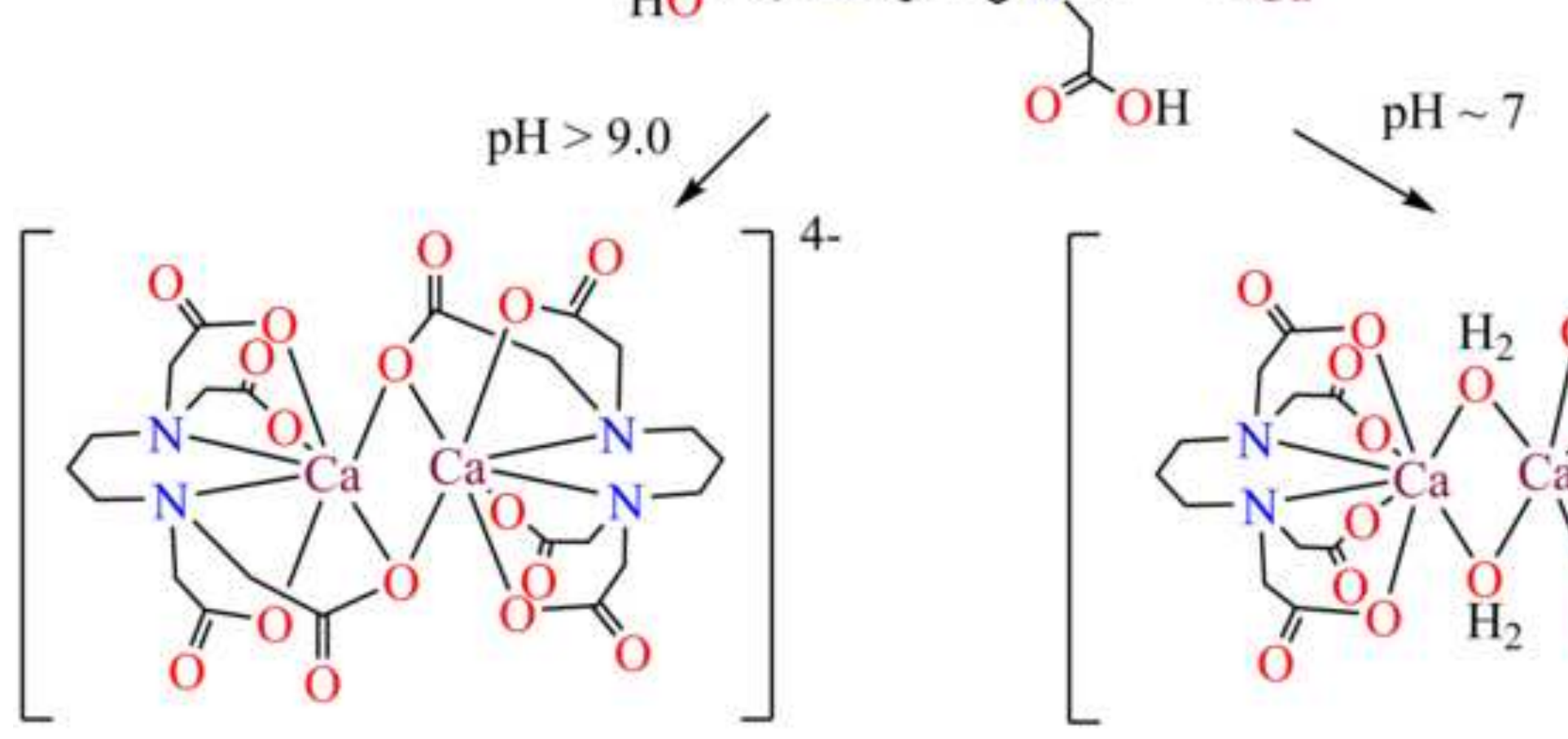

3
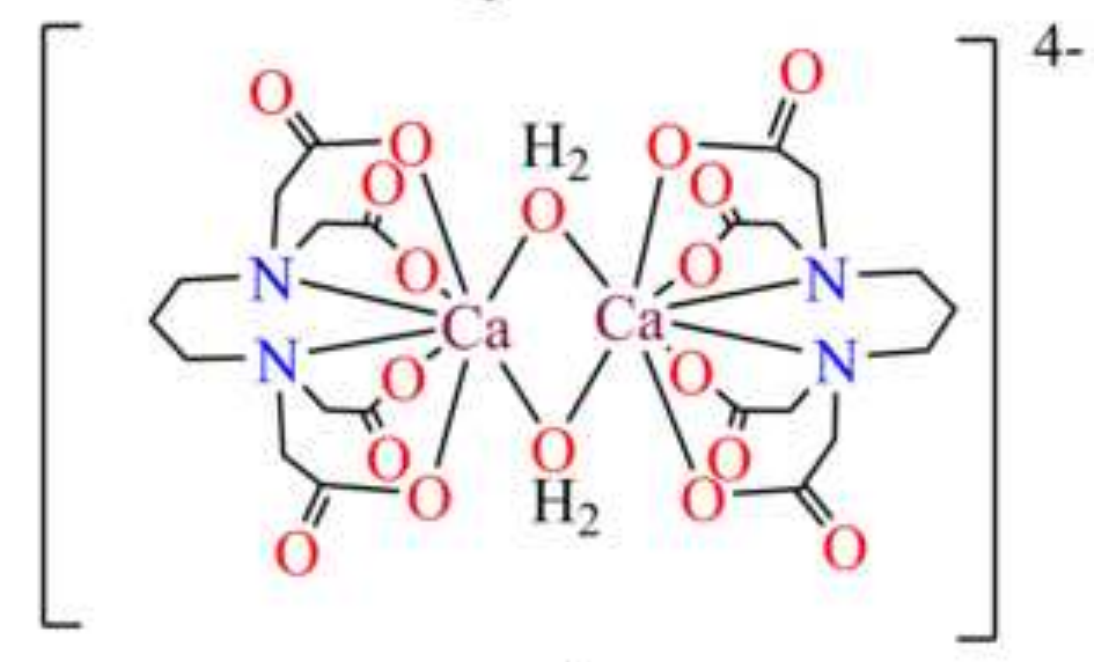

4 


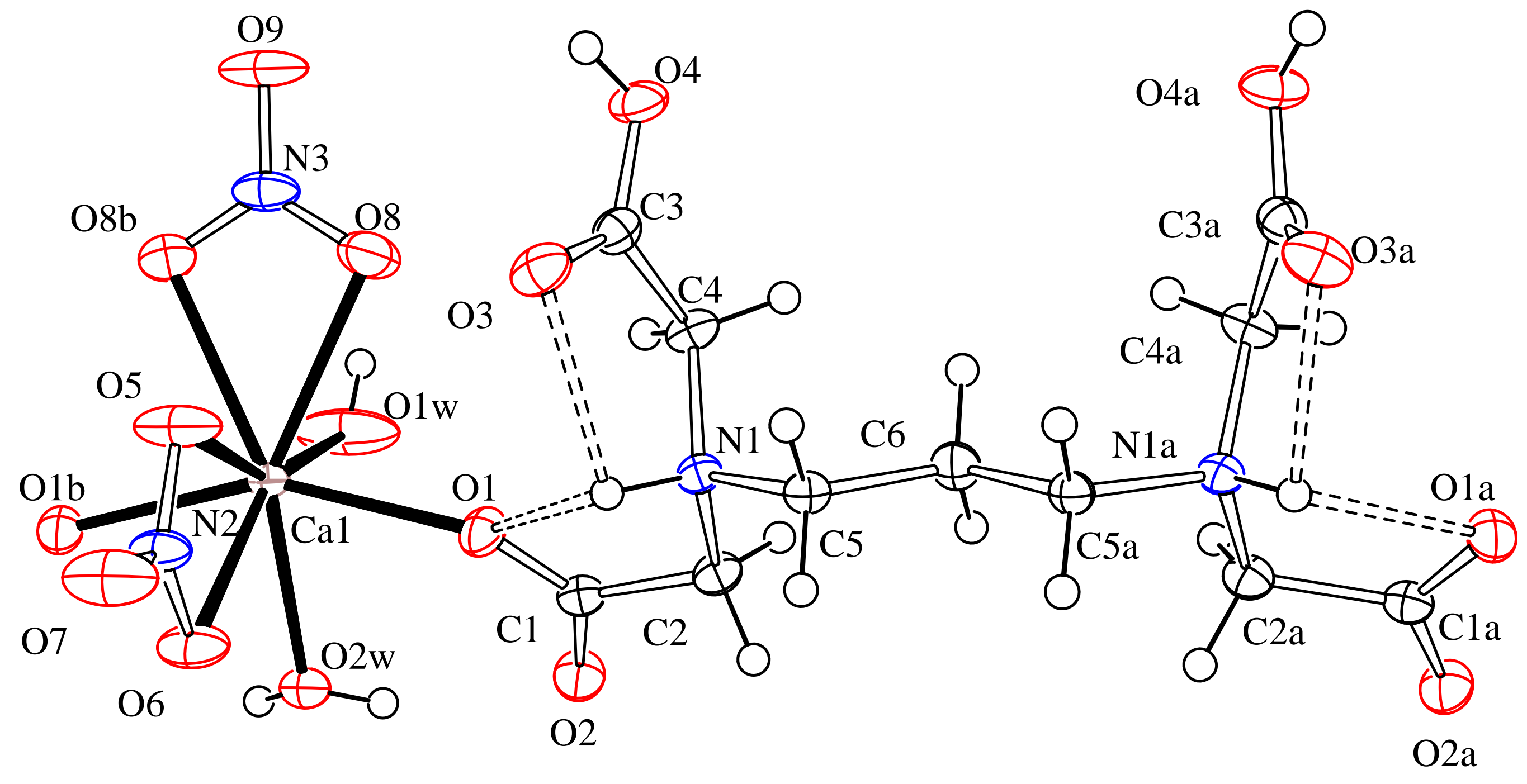




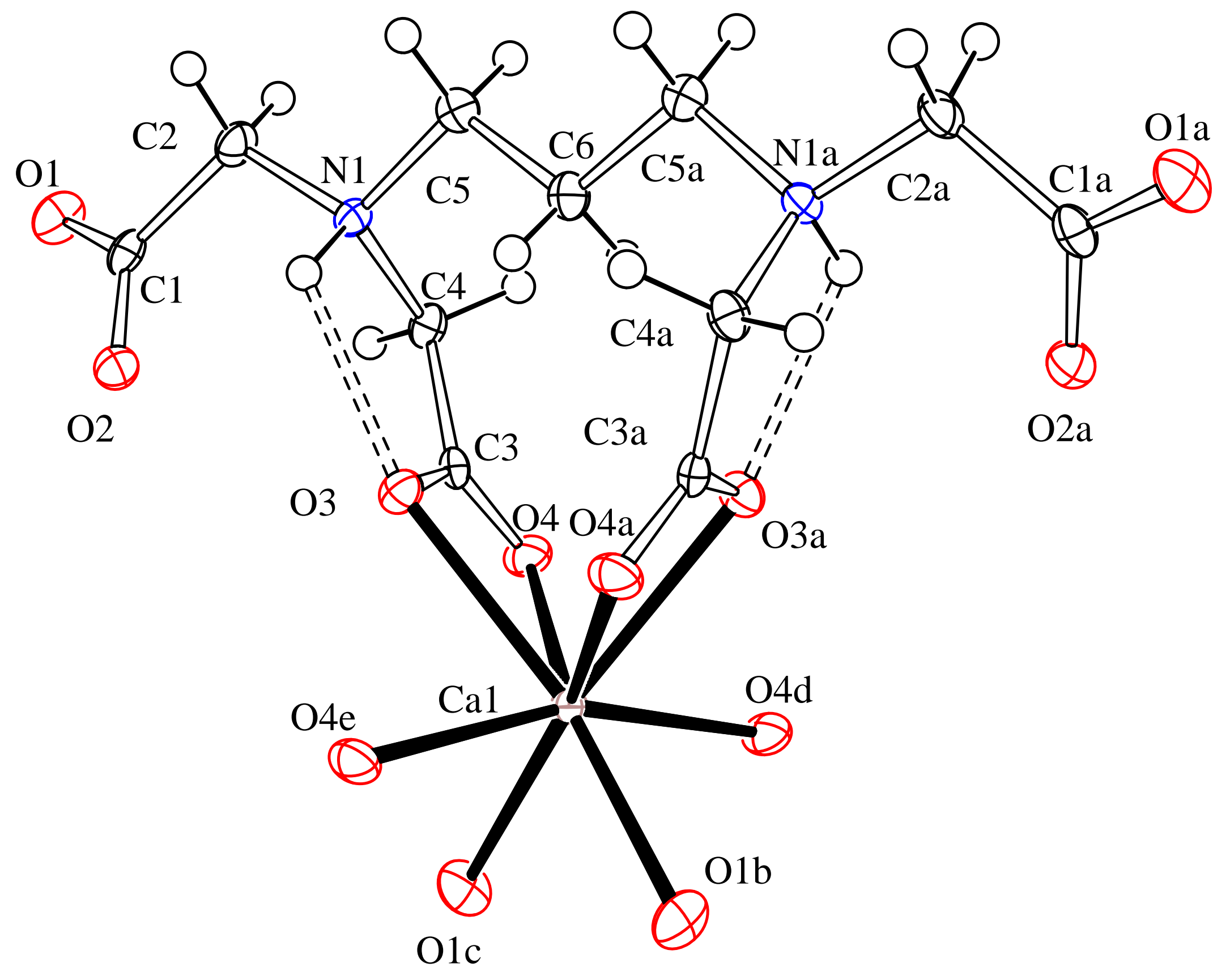




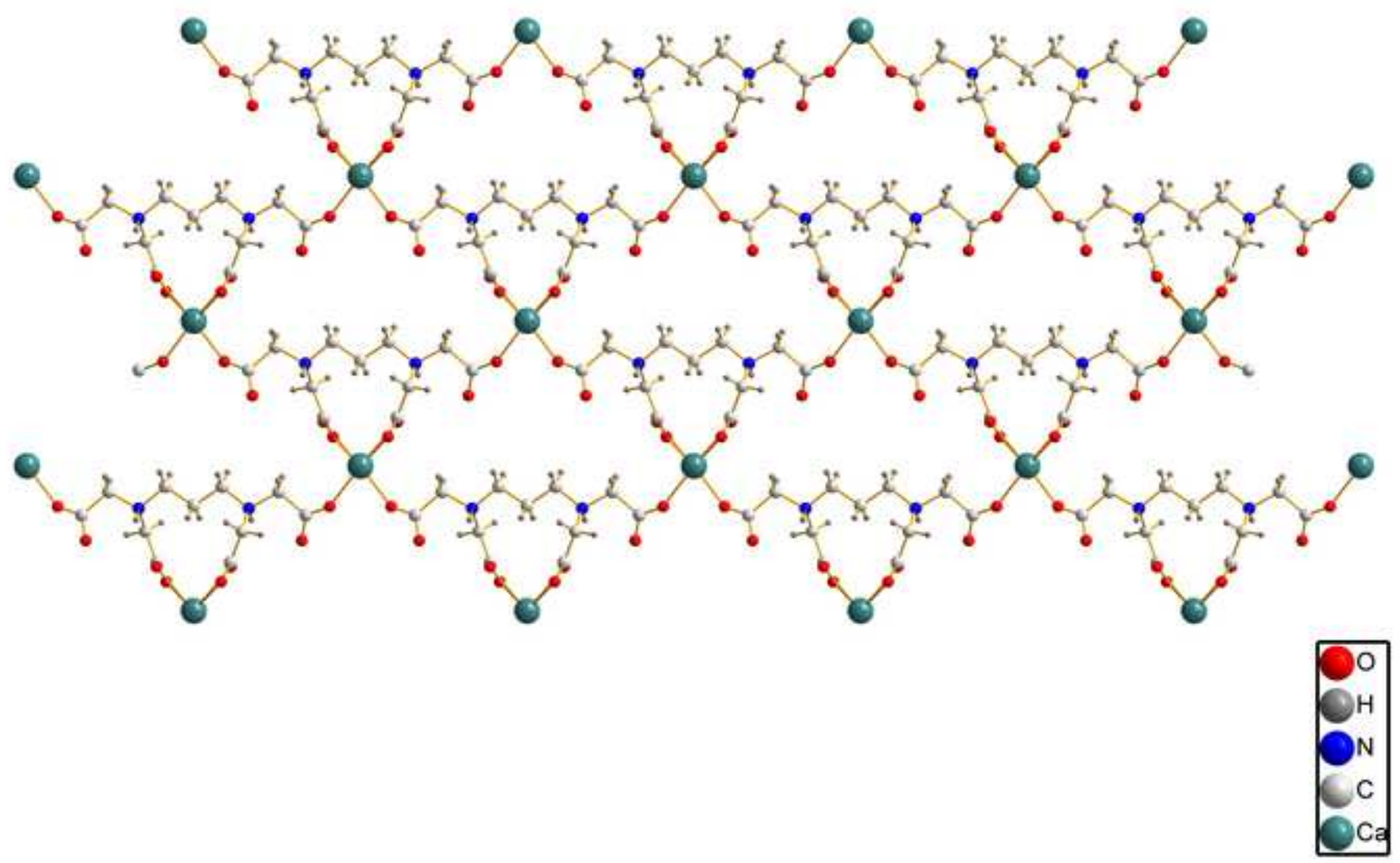




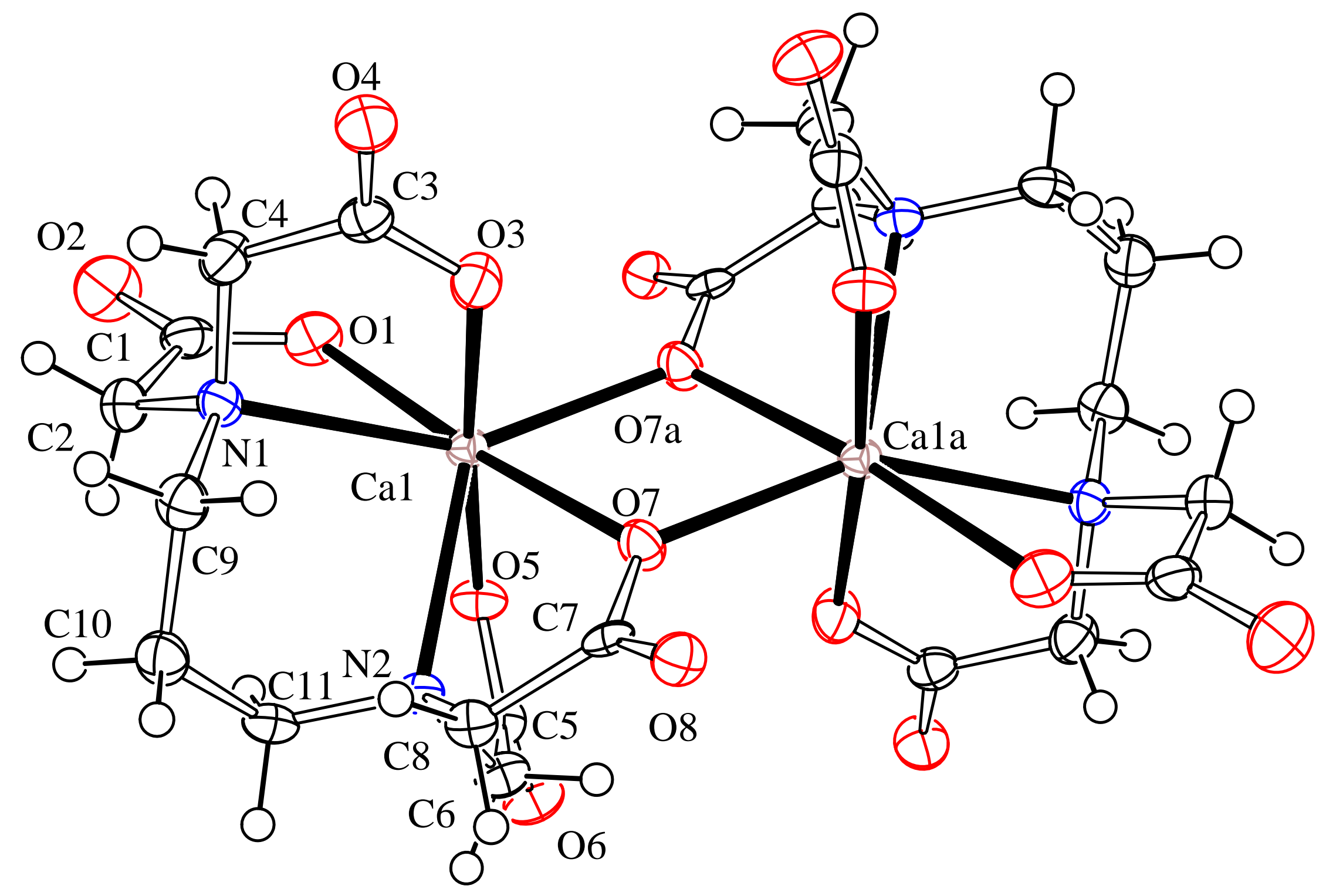



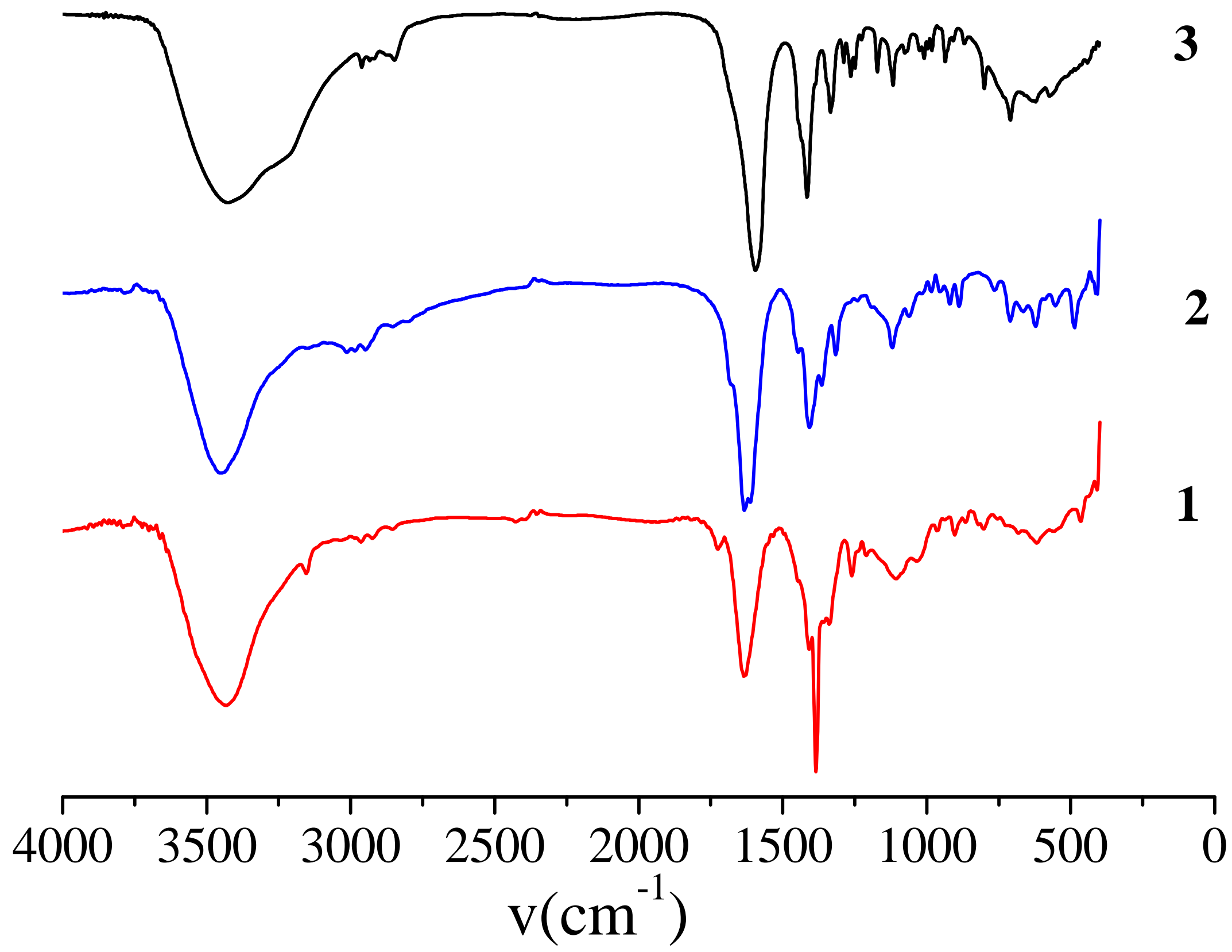


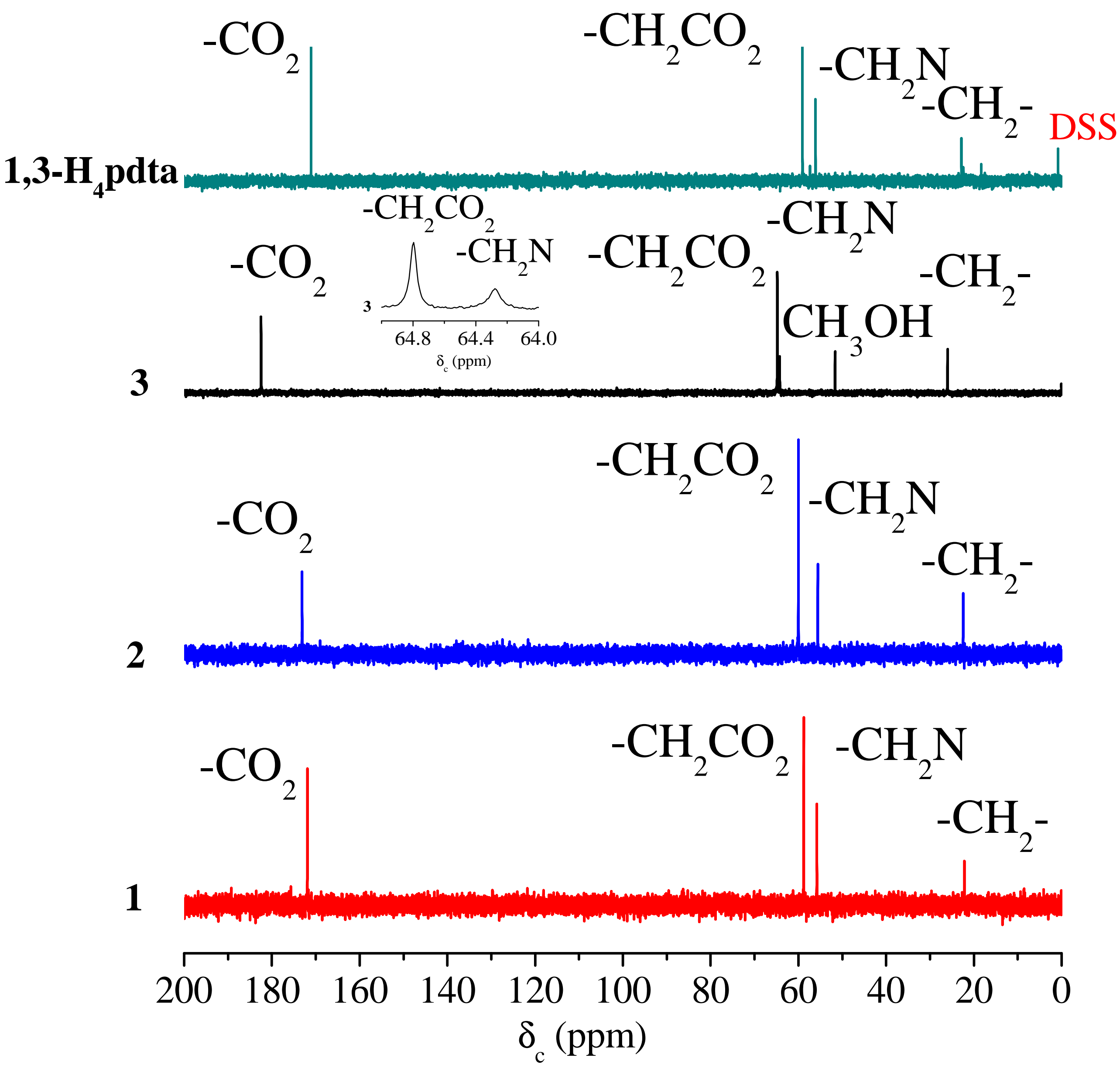


Table 1: The crystallographic data and refinements for $\left[\mathrm{Ca}\left(1,3-\mathrm{H}_{4} \mathrm{pdta}\right)\left(\mathrm{NO}_{3}\right)_{2}\left(\mathrm{H}_{2} \mathrm{O}\right)_{2}\right]_{\mathrm{n}}(\mathbf{1})$,

$\left[\mathrm{Ca}\left(1,3-\mathrm{H}_{2} \mathrm{pdta}\right)\right]_{\mathrm{n}} \cdot \mathrm{nH}_{2} \mathrm{O}(\mathbf{2})$ and $\mathrm{K}_{4}\left[\mathrm{Ca}_{2}(1,3-\mathrm{pdta})_{2}\right] \cdot 2 \mathrm{H}_{2} \mathrm{O} \cdot 2 \mathrm{CH}_{3} \mathrm{OH}(\mathbf{3})$.

\begin{tabular}{|c|c|c|c|}
\hline & 1 & 2 & 3 \\
\hline Empirical formula & $\mathrm{C}_{11} \mathrm{H}_{22} \mathrm{CaN}_{4} \mathrm{O}_{16}$ & $\mathrm{C}_{11} \mathrm{H}_{18} \mathrm{CaN}_{2} \mathrm{O}_{9}$ & $\mathrm{C}_{24} \mathrm{H}_{40} \mathrm{Ca}_{2} \mathrm{~K}_{4} \mathrm{~N}_{4} \mathrm{O}_{20}$ \\
\hline $\mathrm{Mr}$ & 506.40 & 362.35 & 941.16 \\
\hline Crystal system & Orthorhombic & Monoclinic & Monoclinic \\
\hline Space group & $P m n 2_{1}$ & $C 2 / c$ & $P 2{ }_{1} / c$ \\
\hline $\mathrm{a} / \AA$ & $14.395(2)$ & $15.0662(6)$ & $13.7023(9)$ \\
\hline $\mathrm{b} / \AA$ & $8.269(1)$ & $12.4906(5)$ & $17.005(1)$ \\
\hline $\mathrm{c} / \AA$ & $8.2436(9)$ & $8.1578(3)$ & $7.9504(5)$ \\
\hline \multicolumn{4}{|l|}{$\alpha /^{\circ}$} \\
\hline$\beta /^{\circ}$ & & $107.611(4)$ & $92.397(6)$ \\
\hline \multicolumn{4}{|l|}{$\gamma /^{\circ}$} \\
\hline $\mathrm{V} / \AA$ & $981.2(2)$ & $1463.2(1)$ & $1850.9(2)$ \\
\hline $\mathrm{Z}$ & 2 & 4 & 2 \\
\hline $\mathrm{D}_{\text {cald }} / \mathrm{g} \cdot \mathrm{cm}^{-3}$ & 1.714 & 1.645 & 1.689 \\
\hline$\mu / \mathrm{mm}$ & 0.413 & 0.481 & 0.844 \\
\hline$F(000)$ & 528.0 & 760.0 & 976.0 \\
\hline Flack parameter & $0.01(4)$ & & \\
\hline Refl. measured & 7432 & 5135 & 7193 \\
\hline Refl. unique & 2405 & 1704 & 3612 \\
\hline$R_{\text {int }}$ & 0.0574 & 0.0478 & 0.0551 \\
\hline GoF on $\mathrm{F}^{2}$ & 1.131 & 1.062 & 1.016 \\
\hline Final Rindices $[I>2 \sigma(I)]$ & $R_{1}=0.0399$ & $R_{1}=0.0407$ & $R_{1}=0.0590$ \\
\hline
\end{tabular}




$$
\mathrm{w} R_{2}=0.1045
$$

$R_{1}=0.0429$

$\mathrm{w} R_{2}=0.1078$ $\mathrm{w} R_{2}=0.0785$

$R_{1}=0.0561$

$\mathrm{w} R_{2}=0.0852$ $\mathrm{w} R_{2}=0.1452$

$R_{1}=0.0821$

$\mathrm{w} R_{2}=0.1589$ 
Table 2. Comparisons of the selected bond distances (Å), coordination number (C.N.) of calcium ion and dentate number (D.N.) of 1,3-pdta (or edta) for $\left[\mathrm{Ca}\left(1,3-\mathrm{H}_{4} \text { pdta }\right)\left(\mathrm{NO}_{3}\right)_{2}\left(\mathrm{H}_{2} \mathrm{O}\right)_{2}\right]_{\mathrm{n}} \quad$ (1), $\quad\left[\mathrm{Ca}\left(1,3-\mathrm{H}_{2} \text { pdta }\right)\right]_{\mathrm{n}} \cdot \mathrm{nH}_{2} \mathrm{O} \quad$ (2) $\quad$ and $\mathrm{K}_{4}\left[\mathrm{Ca}_{2}(1,3-\text { pdta })_{2}\right] \cdot 2 \mathrm{H}_{2} \mathrm{O} \cdot 2 \mathrm{CH}_{3} \mathrm{OH} \quad(3), \mathrm{Ca}_{2}\left(\mathrm{H}_{2} \mathrm{O}\right)_{6}\left[\left(\mathrm{Ca}_{2}(1,3-\text { pdta })_{2}\left(\mathrm{H}_{2} \mathrm{O}\right)_{2}\right] \cdot 4 \mathrm{H}_{2} \mathrm{O}\right.$ (4) [9] , $\mathrm{Ca}\left(\mathrm{H}_{2} \mathrm{O}\right)_{2}\left[\mathrm{Ca}(\right.$ edta $\left.)\left(\mathrm{H}_{2} \mathrm{O}\right)\right] \cdot 4 \mathrm{H}_{2} \mathrm{O} \quad$ (5) $\quad[27], \quad \mathrm{Sr}\left(\mathrm{H}_{2} \mathrm{O}\right)_{3}\left[\mathrm{Ca}(\right.$ edta $\left.)\left(\mathrm{H}_{2} \mathrm{O}\right)\right] \cdot \mathrm{H}_{2} \mathrm{O} \quad$ (6) [28], $\left[\mathrm{Ni}(\text { phen })_{3}\right]\left[\mathrm{Ca}(\right.$ edta $\left.)\left(\mathrm{H}_{2} \mathrm{O}\right)_{2}\right] \cdot 10.5 \mathrm{H}_{2} \mathrm{O}(7)$ [29], $\left[\mathrm{Ca}\left(\mathrm{H}_{2} \mathrm{edta}\right)\left(\mathrm{H}_{2} \mathrm{O}\right)\right] \cdot \mathrm{H}_{2} \mathrm{O}(\mathbf{8})$ [30].

\begin{tabular}{cccccc}
\hline Entry & $\mathrm{Ca}-$ Ocarboxy & $\mathrm{Ca}-\mathrm{N}_{\mathrm{av}}$ & $\mathrm{Ca}-\mathrm{Ow}_{\mathrm{av}}$ & $\mathrm{C} . \mathrm{N}$. & D.N. \\
\hline $\mathbf{1}$ & $2.321(3)$ & --- & $2.418(4)$ & 8 & 2 \\
$\mathbf{2}$ & $2.466(2)$ & --- & -- & 8 & 6 \\
$\mathbf{3}$ & $2.379(3)$ & $2.566(3)$ & --- & 7 & 6 \\
$\mathbf{4}$ & $2.439(3)$ & $2.682(3)$ & $2.500(3)$ & 8 & 8 \\
$\mathbf{5}$ & $2.422(5)$ & $2.667(5)$ & $2.396(5)$ & $7 / 8$ & 9 \\
$\mathbf{6}$ & $2.534(8)$ & $2.573(8)$ & $2.493(8)$ & 8 & 9 \\
$\mathbf{7}$ & $2.395(2)$ & $2.638(3)$ & $2.485(3)$ & 8 & 6 \\
$\mathbf{8}$ & $2.356(1)$ & --- & $2.344(1)$ & 6 & 5 \\
\hline
\end{tabular}


Table 3. Solution ${ }^{13} \mathrm{C}$ NMR spectral data (in ppm) of 1,3- $\mathrm{H}_{4}$ pdta, $\mathbf{1}, 2$ and $\mathbf{3}$.

\begin{tabular}{cccccc}
\hline Complex & $-\mathrm{CH}_{2-}$ & $-\mathrm{CH}_{2} \mathrm{~N}$ & $-\mathrm{NCH}_{2} \mathrm{CO}_{2}$ & $-\mathrm{CO}_{2}$ & $\mathrm{CH}_{3} \mathrm{OH}$ \\
\hline $1,3-\mathrm{H}_{4}$ pdta & 22.22 & 55.88 & 58.81 & 171.90 & --- \\
$\mathbf{1}$ & 22.15 & 55.78 & 58.78 & 171.90 & --- \\
$\mathbf{2}$ & 22.45 & 55.57 & 59.99 & 173.11 & --- \\
$\mathbf{3}$ & 26.00 & 64.28 & 64.80 & 182.47 & 51.59 \\
\hline
\end{tabular}

